\title{
Degumming Role of Sunflower Oil (Helianthus annuus) on Biodiesel Quality
}

\author{
MIHAELA GABRIELA DUMITRU* \\ University of Craiova, Faculty of Science, Department of Chemistry, 107i Calea Bucuresti, 200585, Craiova Romania
}

\begin{abstract}
Biodiesel, known as fatty acid methyl ester, has become more attractive as an alternative fuel for diesel engine because of its environmental benefits and the fact that it is made from renewable resources such as vegetable oil and animal fats by reacting them with shortchain alcohols. Biodiesel has become increasingly important due to the following advantages: it is renewable, biodegradable, non-toxic, and eco-friendly. Crude sunflower oil may be a cheap source for biodiesel production. However, it contains high amount of phosphorus, which can inhibit the action of the catalyst during transesterification. Phosphorus removal from vegetable oils applied for diesel fuel is an essential process, since the presence of phosphors in directuse to the diesel engine might cause plugging in the engine filters, lines and injectors. In the biodiesel production, the use of crude vegetable oils without degumming might decrease conversion rate and hard to separate glycerol from biodiesel, during and after trans-esterification reaction respectively.Degumming role of crude sunflower oil on physicochemical properties of biodiesel was studied with determination of following parameters: phosphorus content, acidity value, peroxide value, viscosity, density, iodine value and saponification value. Degumming of sunflower oil is realysed by water degumming and by electrolyte degumming followed by a fast decrease of residual phosphorus content. The compared results showed that degumming process of sunflower oil has a role on biodiesel quality.
\end{abstract}

Keywords: Sunflower oil, degumming, biodiesel

Oil and fats contain complex organo-phosphorus compound referred to as phospholipids (phosphatides). All vegetable oils contains two types of phospholipids: hydratable phospholipids and non-hydratable phospholipids [1]. The basic structure of the phospholipids is given in figure 1[2].

Phospholipids are amphiphilic compounds: the phosphate-containing polar head-group composes the hydrophilic part, while the glycerol-backbones, as well as the fatty acids compose the hydrophobic part. The solubility of phospholipids in water depends on the headgroup type and the hydrocarbon chain length. Four classes of phospholipids (PLS) can be distinguished as a function of PLs solubility [2].

Class I includes phospholipids which are insoluble in water.
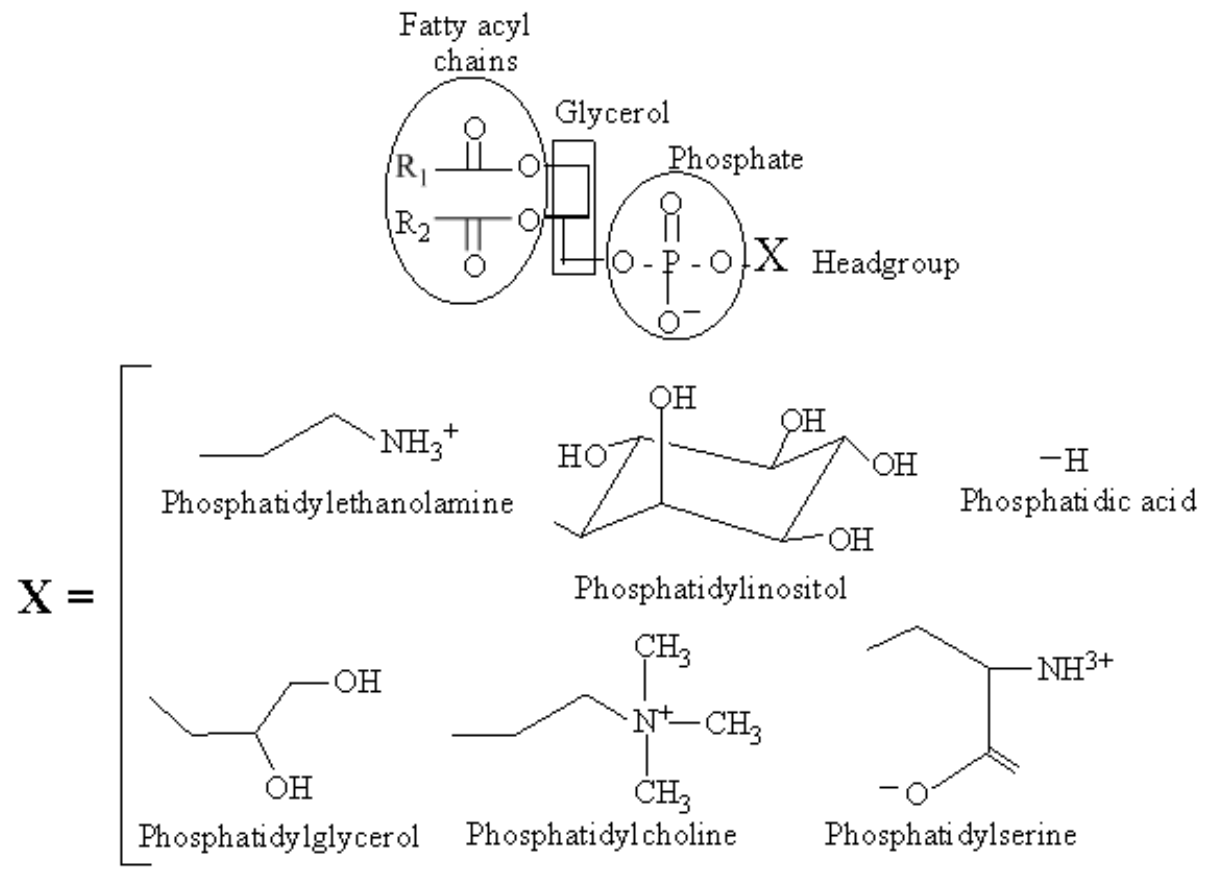

Fig. 1. Structure and major classes of phospholipids 
accelerated before the completion of alcoholysis. It is reported that the produced soap consumes the catalyst and reduces the catalytic efficiency. The soap formation can cause problems with separation of glycerol from the esters after the reaction is complete. These impurities not only contaminate biodiesel production but reduce biodiesel yield as well [3]. Thus, vegetable oils to be used for biodiesel production must be degummed.

Degumming is the treatment of crude oils with water, salt solutions, or dilute acids such as phosphoric acid to remove phosphatides, waxes and other impurities. Technically, degumming is referred as an operation of purification of seed oils, which normally contain impurities in the colloidal state or dissolved in them. Degumming exploits the affinity of phosphatides for water by converting them to hydrated gums, which are insoluble in oil and readily separated by centrifugal action [4].

The aim of this article is to show the role of degumming process of sunflower oil on biodiesel quality.

In table 1 is show degumming methods of vegetable

\section{Experimental part}

Materials and methods

For the experimental partwe used oil obtained by solvent extraction of sunflower seeds.

Degumming of oil were realysed by water degumming followed by electrolyte degumming [7, 12], ( fig. 2).

Biodiesel. The biodiesel was produced by alkali catalyzed transesterification process, (fig. 3 and 4), in biochemistry lab of Chemistry Department of University of Craiova [13].

\section{Oil and biodiesel characterization}

Phosphorus content analysis

The phosphorus content was determined by ashing the sample in the presence of zinc oxide followed by the spectrometric measurement of phosphorus as a blue phosphomolybdic acid complex [14].The absorbance was measured at $650 \mathrm{~nm}$ by using a Cary 50 spectrophotometer. The phosphorus content was determined by means of

Table 1

DEGUMMING METHODS OF VEGETABLE OIL

\begin{tabular}{|c|c|c|c|}
\hline Methods & Principle & Methods & Principle \\
\hline $\begin{array}{l}\text { Water } \\
\text { degumming }\end{array}$ & $\begin{array}{l}\text { Treatment of crude oil with hot } \\
\text { water/steam; the gums for lecithin } \\
\text { production [5] }\end{array}$ & $\begin{array}{l}\text { Ethanolamine } \\
\text { degumming }\end{array}$ & $\begin{array}{l}\text { Treatment with etanol, diethanolamine, } \\
\text { simultaneous degumming and } \\
\text { deacidification [8] }\end{array}$ \\
\hline $\begin{array}{l}\text { Acid } \\
\text { degumming }\end{array}$ & $\begin{array}{l}\text { Treatment of crude/water } \\
\text { degummed oil with acid solution, } \\
\text { the gums for animal feed [5] }\end{array}$ & $\begin{array}{l}\text { Supercritical } \\
\mathrm{CO}_{2} \\
\text { degumming }\end{array}$ & $\begin{array}{l}\text { Extraction of phospholipid by } \\
\text { supercritical } \mathrm{CO}_{2}[9]\end{array}$ \\
\hline $\begin{array}{l}\text { Acid refining } 7 \\
\text { special } \\
\text { degumming }\end{array}$ & $\begin{array}{l}\text { Treatment of crude oil/water } \\
\text { degummed oil with acid solution, } \\
\text { then partially neutralized with alkali } \\
\text { [6] }\end{array}$ & $\begin{array}{l}\text { Membrane } \\
\text { degumming }\end{array}$ & $\begin{array}{l}\text { Passage of crude oil through a } \\
\text { semipermeable membrane retaining } \\
\text { phospholipids [10] }\end{array}$ \\
\hline $\begin{array}{l}\text { Electrolyte } \\
\text { degumming }\end{array}$ & $\begin{array}{l}\text { Treatment with electrolyte solution } \\
{[7]}\end{array}$ & $\begin{array}{l}\text { Enzymatic } \\
\text { degumming }\end{array}$ & $\begin{array}{l}\text { Modification of phospholipids with } \\
\text { enzymes to facilitate the hydration [11] }\end{array}$ \\
\hline $\begin{array}{l}\text { S.O.F.T. } \\
\text { degumming }\end{array}$ & $\begin{array}{l}\text { Degumming using chelating agent } \\
\text { (EDTA) }[5]\end{array}$ & - & - \\
\hline
\end{tabular}

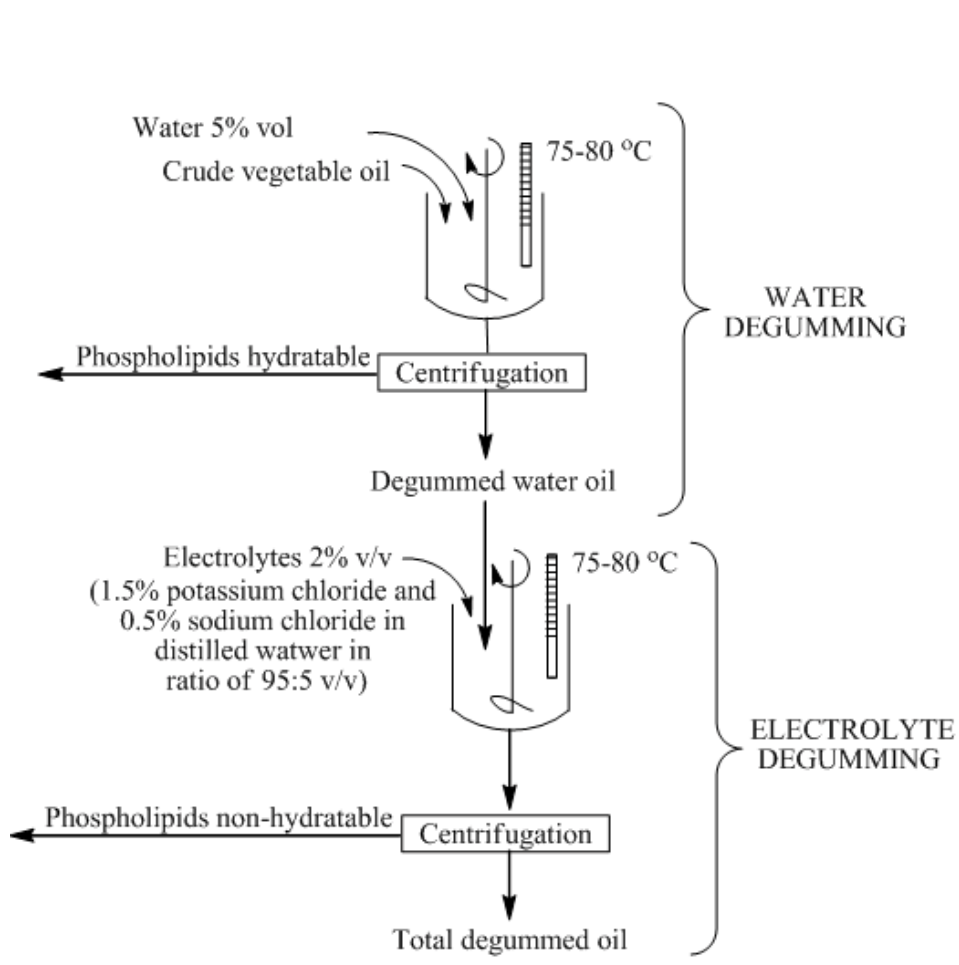

Fig. 2. Degumming of sunflower oil by wáter degumming and by electrolyte degumming

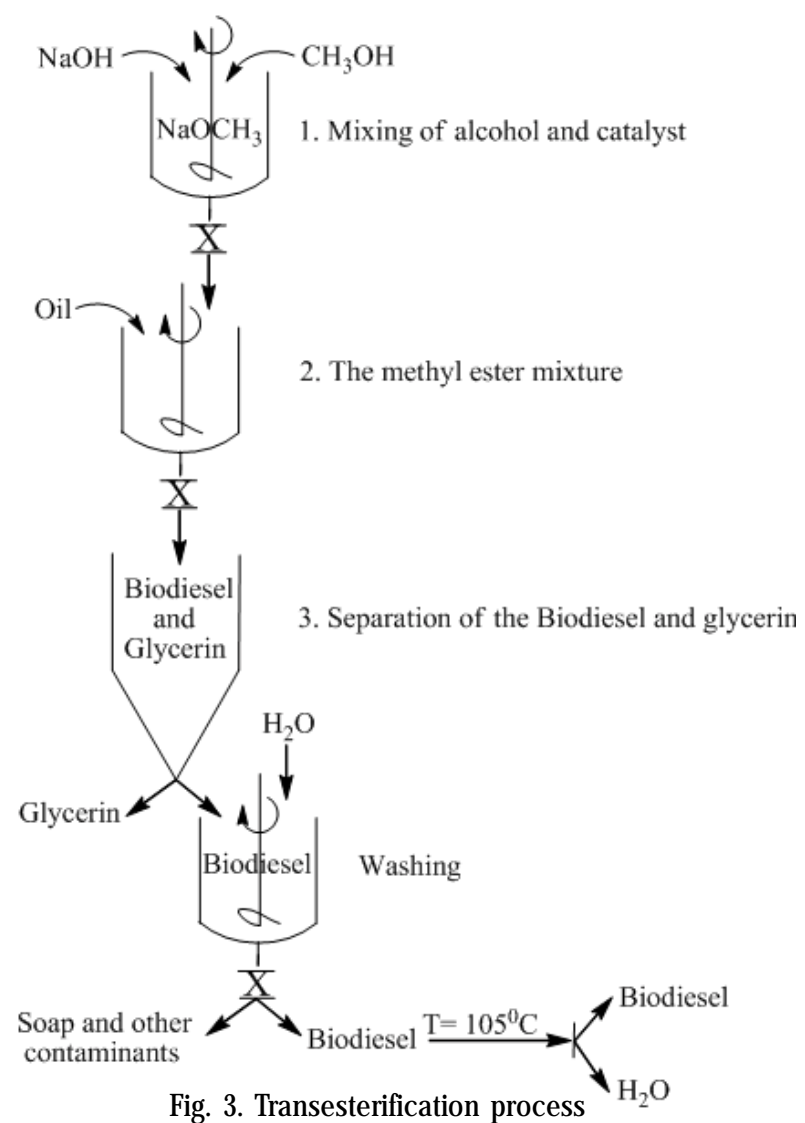




$$
\mathrm{ROH}+\mathrm{B} \rightleftharpoons \mathrm{RO}^{-}+\mathrm{BH}^{+}
$$<smiles>[R]C(=O)OCC(COC([R])([R])[O-])OCC(COC([R4])=O)[C@H](COC([R4])=O)OC([R4])=O</smiles>

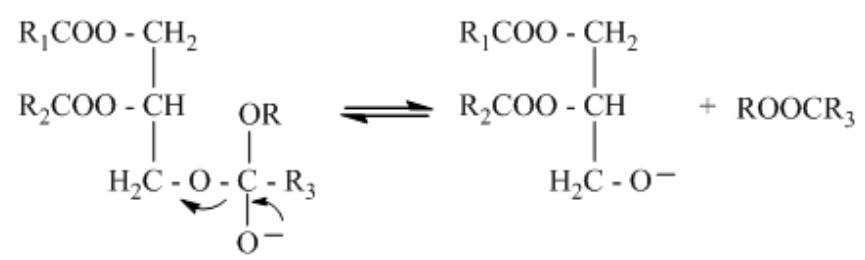

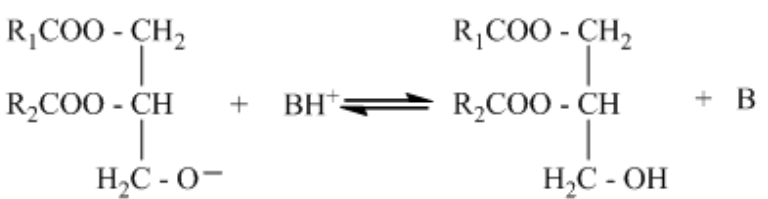

Fig. 4. Mechanism of the base-catalyzed transesterification of vegetable oils

standard curve using di-potassium hydrogen phosphate as a standard, (fig. 5).

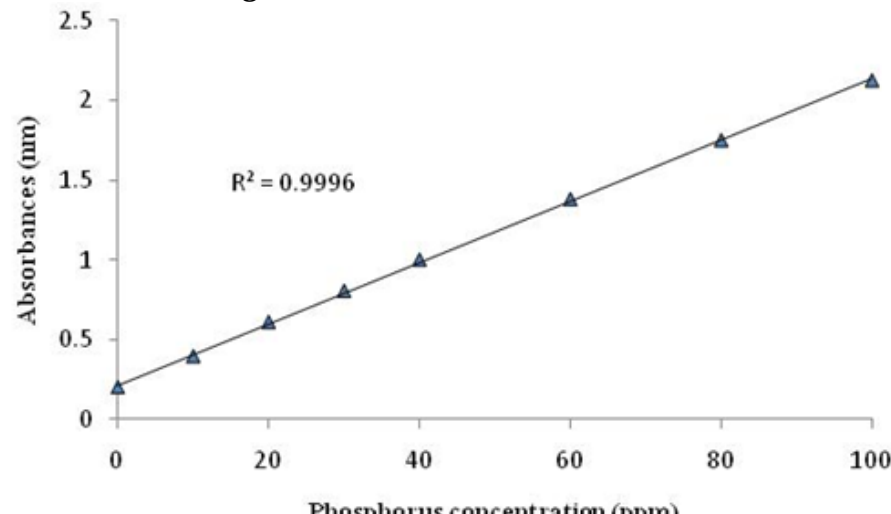

Phosphorus concentration (ppm)

Fig. 5. Calibration curve for phosphorus determination

Acidity value (AV)

The AV was determined according the AOAC method (969.17) as follows. A known weight ( $2 \mathrm{~g}$ ) of the oil or biodiesel sample was dissolved in a neutral ethyl alcohol $(30 \mathrm{~mL})$; the mixture was boiled in a water bath for $2 \mathrm{~min}$ and then titrated with a potassium hydroxide solution ( 0.1 $\mathrm{N})$ in the presence of phenolphthalein as an indicator. Acid value is expressed as $\mathrm{mg} \mathrm{KOH}$ required to neutralize the acidity in one gram of oil $[15,16]$.

\section{Peroxide value (PV).}

The $P V$ was determined according to the $A O A C$ method (965.33). A known weight of the oil or biodiesel sample $(2.5 \mathrm{~g})$ was dissolved in a mixture consisting of glacial acetic acid: chloroform ( $30 \mathrm{~mL}, 3: 2$, and $v / \mathrm{v}$ ), then freshly prepared saturated potassium iodide solution $(1 \mathrm{~mL})$ was added. Distilled water (30 mL) was added then titrated slowly with sodium thiosulfate solution $(0.1 \mathrm{~N})$ in the presence of a starch solution (1\%) as an indicator. PV is expressed as the milliequivalent of the $\mathrm{O}_{2} \mathrm{Kg}^{\prime 1}$ sample [15, 17].

\section{Viscosity}

The viscosity determination by ASTM D445. The determination of viscosity was carried out by introducing about $50 \mathrm{~mL}$ of sample oil into a clean dried viscosity tube.
This is done by inverting the tube thinner arm into the oil sample and then using suction force to draw up the oil to the upper timing mark of the viscometer. The viscometer was placed into a holder and inserted into a constant temperature bath set at a desired temperature of $40^{\circ} \mathrm{C}$ and 30 min for the sample to come to the bath temperature. The suction force was then applied to the thinner arm to draw the sample slightly above the upper timing mark. The afflux time was recorded by timing the flow of the sample as it flow freely from the upper timing mark to the lower timing mark [18]. The viscosity is calculated by means of the following equation:

$$
\begin{aligned}
& \mathrm{V}=\mathrm{c} \cdot \mathrm{t} \\
& \text { where: } V=\text { viscosity in }\left(\mathrm{mm}^{2} \mathrm{~s}^{-1}\right) ; t=\text { time in seconds; } \\
& c=\text { viscosity tube constant. }
\end{aligned}
$$

\section{Density}

The density was determined at $15^{\circ} \mathrm{C}$ using a $50 \mathrm{~mL}$ bottle pycnometer that was washed thoroughly with detergent, water and petroleum ether according to method described in AOAC (2005) [17, 18].

\section{lodine value (IV)}

The IV was determined using the Hanus method, as described in AOAC (920.158). A known weight of the oil or biodiesel sample $(0.2 \mathrm{~g})$ was dissolved in chloroform (20 $\mathrm{mL})$, then Hanus iodine $(\mathrm{I}+\mathrm{Br} / \mathrm{AcOH})$ solution $(25 \mathrm{~mL})$ was added and left in the dark for $30 \mathrm{~min}$. Potassium iodide solution ( $10 \mathrm{~mL}, 15 \%)$ was added, followed by freshly distilled water ( $100 \mathrm{~mL}$ ), and the excess iodine was titrated by sodium thiosulfate $(0.1 \mathrm{~N})$ until the yellow color of the solution had almost disappeared. Titration was continued after adding a few drops of starch as an indicator until the blue color had entirely disappeared. A blank was conducted where the total halogen content of the Hanus solution (25 $\mathrm{mL}$ ) was determined by sodium thiosulfate solution without the addition of oil. IV is expressed as grams of $\mathrm{I}_{2}$ absorbed by $100 \mathrm{~g}$ oil or biodiesel sample [15, 16].

\section{Saponification number}

Saponification value (SV) was determined according to the AOAC method (920.160). A known weight of the oil or biodiesel sample $(5 \mathrm{~g})$ was heated with alcoholic potassium hydroxide ( $50 \mathrm{~mL}, 0.5 \%$ ) for about $30 \mathrm{~min}$. The reaction mixture was cooled down and then titrated with hydrochloric acid solution ( $0.5 \mathrm{~N}$ ) using phenolphthalein as an indicator. A blank was performed where the same volume of alcoholic potassium hydroxide solution without oil was treated similarly as in the experiment. The saponification number is expressed as $\mathrm{mg} \mathrm{KOH}$ required to saponify $1 \mathrm{~g}$ oil or biodiesel sample [15, 19].

\section{The efficiency of degumming processes}

To evaluate the efficiency of degumming processes, the phosphorus content determination in crude and degummed oil samples was used using the following equation [20]:

$$
\text { Efficiency }=\left(P_{-}-P_{r}\right) / P_{i}
$$

where $P$ is the total phosphorus content of the crude oil ( $\mathrm{mg} \mathrm{Kg}^{-1}$ ) and $\mathrm{P}$ is the residual phosphorus content in degummed oils $\left(\mathrm{mg} \mathrm{Kg}^{-1}\right)$.

\section{Results and discussions}

Physico-chemical properties

The results obtained from the characterization of sunflower oil and biodiesel are presented in table 2.

The efficiency of degumming processes is $96.6 \%$. 


\begin{tabular}{|c|c|c|c|c|c|}
\hline Parameter & $\begin{array}{c}\text { Crude } \\
\text { sunflower oil }\end{array}$ & $\begin{array}{l}\text { Degummed } \\
\text { sunflower oil }\end{array}$ & $\begin{array}{l}\text { Biodiesel from non- } \\
\text { degummed } \\
\text { sunflower oil }\end{array}$ & $\begin{array}{l}\text { Biodiesel from } \\
\text { degummed } \\
\text { sunflower oil }\end{array}$ & \\
\hline $\begin{array}{l}\text { Phosphorus content, mg } \\
\mathrm{Kg}^{-1}\end{array}$ & 390 & 12.9 & 9.5 & 0.9 & \\
\hline $\begin{array}{l}\text { Acid value, } \\
\mathrm{mg} \mathrm{KOH} \mathrm{g-1}\end{array}$ & 3.9 & 2.1 & 0.45 & 0.29 & Table 2 \\
\hline $\begin{array}{l}\text { Peroxide value, } \mathrm{mEq} \mathrm{O}_{2} \\
\mathrm{Kg}^{-1}\end{array}$ & 8.7 & 5.6 & 3.8 & 4.2 & CHARACTERISTICS \\
\hline$V^{-}$iscosity $40^{\circ} \mathrm{C}, \mathrm{mm}^{2} \mathrm{~s}^{-I^{-}}$ & 9.2 & 6.3 & 4.8 & 3.9 & $\begin{array}{c}\text { OBTAINED FOR } \\
\text { SUNFLOWER OIL AND }\end{array}$ \\
\hline $\begin{array}{l}\text { Density } 15^{\circ} \mathrm{C} \text {, } \\
\mathrm{g} \mathrm{cm}^{-3}\end{array}$ & 0.920 & 0.912 & 0.908 & 0.875 & BIODIESEL \\
\hline Iodine value, $\mathrm{g} \mathrm{I}_{2} 100 \mathrm{~g}^{-1}$ & 145 & 120 & 110 & 101 & \\
\hline $\begin{array}{l}\text { Saponification value, mg } \\
\mathrm{KOH} \mathrm{g}\end{array}$ & 180 & 169.5 & 160 & 145 & \\
\hline
\end{tabular}

Phosphorus is an indication of the presence of phospholipids in feedstocks from plant origins. Crude sunflower oil has a high content of phospholipids, which are the major constituents of the biological membranes [21]. Depending on the raw materials used, degumming becomes an indispensable step for biodiesel production to achieve phospholipids removal and to reduce the final phosphorus content below the specified limits [22]. Phosphorus reduces the combustion temperature, leads to deposits in the combustion chamber and eventually changes the emission behaviour. The life and efficiency of catalytic converters are affected by the presence of phosphorus compounds. Furthermore phospholipids tend to form particles with water and can cause filter blockage [23]. In its turn, the phosphorus released in a ionic state or associated with carbonil radicals react with the engine metal structure, forming iron-phosphorus coordination compounds. When these coordination compounds gather into the metal mass, mechanical properties of the engine component parts can get degraded, resulting in their deterioration [24]. Using oil with a high level of phospholipids results in the formation of deposits, which coke in hot engine sections - combustion chamber and nozzle holes [25].

Phospholipids are responsible for the fouling of valves and cylinders when straight vegetable oils are used (gumming phenomenon). Gums can cause problems during the transportation of fuels by settling and forming deposit on tanks walls or clogging pipelines. In engine where vegetable oil is used, excess phosphorus (gums) in the fuel can cause damage to catalytic converters since it can coat the inside of the converters or coking within the engine.

Therefore, it must be removed from the oil through an appropriate degumming process [26].

The phosphorus content of crude sunflower oil was 390 $\mathrm{mg} \mathrm{Kg}^{-1}$, for degummed oil was $9.5 \mathrm{mg} \mathrm{Kg}^{-1}$ and for biodiesel obtained from crude oil was $0.9 \mathrm{mg} \mathrm{Kg}^{-1}$. The phosphorus content is decreasing with an influence on the qualitative índices of biodiesel.

Thus, acidity of crude oil was $3.9 \mathrm{mg} \mathrm{KOH} \mathrm{g}^{-1}$, acidity of degummed oil was $2.1 \mathrm{mg} \mathrm{KOH} \mathrm{g}^{-1}$, acidity of biodiesel obtained from crude oil was $0.45 \mathrm{mg} \mathrm{KOH} \mathrm{g}^{-1}$.Decrease in acid value is due to the reduction in free fatty acid present in the oil during degumming process. The acid value measures the amount of unreacted acids remaining in the finished fuel, and is also an indicator of oxidized fuel [26]. $A$ high acid value in the fuel leads to corrosion, abrasion and deposits in the engine. Furthermore the free fatty acids may react with the alkaline components of the lubricating oil and affect its lubricity [27]. Determination of AV is an important test to assess the quality of a particular biodiesel. The higher the acid value the lower the quality of fuel [28].
Peroxide value determination measures the presence of oxidative moieties (i.e., the portion of a molecule bearing characteristic oxidative properties) in a sample. The oxidative moieties usually found in biodiesel are hydroperoxides formed when oxygen from the air reacts with fatty esters. This usually is the first step in the oxidative degradation pathway of biodiesel [15]. Oxidation results in the formation of hydroperoxide molecules, creating acids that attack metals, rubbers, and elastomers. Another unpleasant consequence of oxidation is that it also triggers polymerisation processes-gum formation and sediments that tend to clog filters and nozzle injectors [15]. Although the PV is not regulated by European standards [13], the increase in this value in biodiesel increases the cetane number, reducing the ignition time (the time between fuel injection in the cylinder and the start of ignition) [15].

Peroxide value for crude oil was $8.7 \mathrm{mEq} \mathrm{O} \mathrm{Kg}^{-1}, 5.6$ $\mathrm{mEq} \mathrm{O} \mathrm{Kg}^{-1}$ for degummed oil, $3.8 \mathrm{mEq} \mathrm{O}_{2} \mathrm{Kg}^{-1}$ for biodiesel obtained from crude oil and $4.2 \mathrm{mEq} \mathrm{O}_{2} \mathrm{Kg}^{-1}$ for biodiesel obtained from degummed oil. This change in values is due to the fact that hydroperoxides are the primary products formed during oxidation, but they are labile intermediate compounds that decompose into several secondary oxidation products, products with action on qualitative parameters.

Viscosity is a physical property responsible for engine performance. The combustion process is dependent of the quality of atomization which in turn is dependent of the fuel properties as density, viscosity and surface tension. Higher viscosity and specific gravity of biodiesel may lead to lower volatility and poor atomization causing incomplete combustion and carbon deposits [13]. The viscosity of the fuel plays an important role in the combustion of fuel. The ease of combustion and thermal efficiency of the engine is directly related to the injected fuel in the combustion chamber through the nozzle and pattern of fuel spray. Lower viscosity may lead to excessive internal pump leakage and the system pressure reaches an unacceptable level. Higher viscosity will block the fuel passage through the pump, affect the flow ability of fuel. These will affect injection during the spray atomization. The viscosity is usually associated with the degree of unsaturation and the molecular size. An increase in double bonds leads to decrease in viscosity. This is due to the fact that presence of double bonds does notallow the fatty acid molecules to stack closely. Hence the molecule does not have a rigid structure and is loosely packed. Studies have also shown that larger molecules result in higher viscosity [29].

The viscosities at $40^{\circ} \mathrm{C}$ ranged from $9.2 \mathrm{~mm}^{2} \mathrm{~s}^{-1}$ for crude oil, $6.3 \mathrm{~mm}^{2} \mathrm{~s}^{-1}$ for degummed oil, $4.8 \mathrm{~mm}^{2} \mathrm{~s}^{-1}$ for biodiesel obtained from crude oil and $3.9 \mathrm{~mm}^{2} \mathrm{~s}^{-1}$ for biodiesel obtained from degummed oil. 
The density of material is defined as the measurement of its mass per unit volume. Biodiesel fuels are, in general, characterized by higher density than conventional petroleum diesel, which means that volumetricallyoperating fuel pumps will inject greater mass of biodiesel than conventional diesel fuel. Fuel density directly affects fuel performance, and some of the engine properties, such as cetane number, heating value and viscosity are strongly connected to density. The density of the fuel also affects the quality of atomization and combustion [26].

The results showed a value for density of $0.920 \mathrm{~g} \mathrm{~cm}^{-3}$ for crude oil, a value for density of $0.912 \mathrm{~g} \mathrm{~cm}^{-3}$ for degummed oil, a value for density of $0.908 \mathrm{~g} \mathrm{~cm}^{-3}$ for biodiesel obtained from crude oil and of $0.875 \mathrm{~g} \mathrm{~cm}^{-3}$ for biodiesel obtained from degummed oil.

Density increases with the increase in the number of double bonds, which means that the more unsaturated the originating oil, the higher the density of the derived methyl ester, to the individual ones [30]. Contamination of the biodiesel significantly affects its density; therefore density can also be an indicator of contamination. The density of biodiesel is typically higher than that of diesel fuel and is dependent on fatty acid composition and purity. As biodiesel is made up of a small number of methyl or ethyl esters that have very similar densities, the density of biodiesel varies between tight limits [31].

The lodine value is a measurement of total unsaturation of fatty acids measured in $\mathrm{g}$ iodine $100 \mathrm{~g}^{-1}$ of biodiesel sample, when formally adding iodine to the double bonds. Biodiesel with high iodine value is easily oxidized in contact with air. The biodiesel with high number of iodine value contains high amounts of unsaturates and will have a low cetane number. lodine value higher than 50 may lead to the decrease of the engine life but in turn give better viscosity characteristics in cooler periods of the year [13]. The iodine value highly depends on the nature and ester composition of the feedstocks used in biodiesel production. Biodiesel with high iodine value tends to polymerise and form deposits on injector nozzles, piston rings and piston ring grooves. The tendency of polymerisation increases with the degree of unsaturation of the fatty acids [31].

The iodine indices decreased from $145 \mathrm{~g} \mathrm{I}_{2} 100 \mathrm{~g} \mathrm{~g}^{-1}$ for crude oil to $120 \mathrm{~g} \mathrm{I}_{2} 100 \mathrm{~g}^{-1}$ for degummed oil and also from $110 \mathrm{~g} \mathrm{I}^{1} 100 \mathrm{~g}^{-1}$ for biodiesel obtained from crude oil to 101 $\mathrm{gl}_{2} 100^{2} \mathrm{~g}^{-1}$ for biodiesel obtained from degummed oil.

Saponification value indicates the amount of saponifiable units (acyl groups) per unitweight of oil. A high SV indicates a higher proportion of low molecular weight fatty acids in the oil or vice versa [32]. Saponification is the process by which the fatty acids in the glycerides of oil are hydrolyzed by analkali. Saponification value is the amount $(\mathrm{mg})$ of alkali required to saponify a definite quantity $(\mathrm{g})$ of an oil or fat. This value is useful for a comparative study of the fatty acid chain length in oils [33].

The saponification indices decreased from $180 \mathrm{mg} \mathrm{KOH}$ $\mathrm{g}^{-1}$ for crude oil to $169 \mathrm{mg} \mathrm{KOH} \mathrm{g}^{-1}$ for degummed oil and also from $160 \mathrm{mg} \mathrm{KOH} \mathrm{g}^{-1}$ for biodiesel obtained from crude oil to $141 \mathrm{mg} \mathrm{KOH} \mathrm{g}^{-1}$ for biodiesel obtained from degummed oil.

\section{Conclusions}

This study examined the role of degumming process on physicochemical properties of biodiesel. The results showed that the degumming process decrease the phosphorus content, acidity value, viscosity value, density value, iodine value and saponification value of biodiesel. The study therefore concluded that degummed oils were a better substitute than non-degummed oils as raw materials for the production of biodiesel fuels.

\section{References}

1. KANAKRAJ, S., DIXIT, S., REHMAN, A., Bangladesh J. Sci. Ind. Res., 49(1), 2014, p. 13.

2. PICHOT, R., WATSON, R. L., \& NORTON, I. T., Int. J. Mol. Sci., 14(6), 2013, p. 11767.

3. KANAKRAJ, S., DIXIT, S., REHMAN, A., Electronic Journal of Energy @Environment, 1(2), 2013, p. 21.

4. SENGAR, G., KAUSHA, P., SHARMA, H. K., KAUR, M., Rev. Chem. Eng., 30(2), 2014, p. 183.

5. GUPTA, M., Practical guide to vegetable oil processing, Academic Press and AOCS Press, London, United Kingdom, 2017, p. 7.

6. DIJ KSTRA, A. J., VAN OPSTAL, M., J. Am. Oil Chem. Soc., 66, 1989, p. 1002.

7. NASIRULLAH, J. Food Lipids, 12, 2005, p. 103.

8. ZUFAROV,O., SCHMIDT, S., SEKRETÁR,S., CVENGRO,J., Eur. J. Lipid Sci. Technol., 111, 2009, p.1.

9. LIST,G.R., KING,J.W., J OHNSON,J.H., WARNER,K., MOUNTS,T.L., J. Am. Oil. Chem. Society, 70, 1993, p. 473.

10. KORIS, A., VATAI,G., Desalination, 148, 2002, p. 149.

11. SAMPAIO, K., ZYAYKINA, N., WOZNIAK, B., TSUKAMOTO, J., DE GREYT, W., CHRISTIAN, V., STEVENS, Eur. J. Lipid Sci. Technol., 117, 2015, p. 81.

12. ZUFAROV, O., SCHMIDT, S., SEKRETAR, S., Acta Chim. Slov., 1(1), 2008, p. 321.

13. DUMITRU, M. G., NICA BADEA, D., TUTUNEA., D., Rev. Chim. (Bucharest), 68, no. 12, 2017, p. 2771.

14.*** AOCS official method Ca 12-55. Phosphorus.

15. SAMIR ABD-ELMONEM, A. I., REHAB FAROUK, M. A., Sci. Technol. Adv. Mater.,16, 2015, p. 1.

16. DUMITRU (BITA), M. G., GRECU, D. R., Bulg. J. Agric. Sci., 16, No. 2, 2010, p. 227.

17 DUMITRU, M. G., TUTUNEA, D., Rev. Chim.(Bucharest), 68, no. 11, 2017, p. 2676.

18. GUTTI, B., SHITTU, S., BAMIDELE S. S., IDRIS B. M. B., ARPN J ournal of Engineering and Applied Sciences, 7(4), 2012, p. 432.

19. DUMITRU (BITA), GRECU, R. D., TUTUNEA, D., POPESCU, A., BICA, M., Rev. Chim. (Bucharest), 61, no. 9, 2010, p. 882.

20. LAMAS, D. L., CONSTENLA, D. T., Biocatal. Agric. Biotechnol., 6, 2016, p. 138.

21. GUPTA, M. K., Sunflower oil. In: Gunstone FD, ed., Vegetable oils in food technology: Composition, properties and uses. Oxford (UK): Wiley-Blackwell, 2002, p. 125.

22. CESARINI, S., RUNE, F. H., NIELSEN, P. M., Biotechnol. Biofuels, 7, 2014, p. 29.

23. RICE, B., FOGARTY,C., LEAHY, J.J ., ROURKE, B.O., Sustainable Energy Ireland, Dublin, 2006, https://www.rug.nl.

24. PIRNA, I., LICA, C. NICOLESCU, M., VOICU, E., RADU, M., GAGEANU, G., FÜRLL C. H., INMATEH - Agricultural Engineering, 32(3), 2010, p. 84.

25. SIDIBE, S. S., BLIN, J., VAITILINGOM, G., AND AZOUMAH, Y., Renew. Sust. Energ. Rev., 14,2010, p. 2748.

26. KANAKRAJ, S., DIXIT, S., REHMAN, A., Int. J. Adv. Res., 1(2), 2013, p. 43.

27. ADEKUNLE, A. S., OYEKUNLE,J. A. O., OBISESAN, O. R., OJ O, 0. S., OJ O, O. S., Energy Reports, 2, 2016, p. 188.

28. SUBROTO, E. Optimization of Jatropha curcas pure plant oil production Groningen]: University of Groningen, 2015.

29. MUSA, N., TERAN, G., YAMAN, S., J. Scientific Res. \& Rep. 9(6), 2016, p. 1.

30. LAKSHMINARAYANAN, A., Thesis testing and preformance measurement of straight vegetable oils as an alternative fuel for diesel engines. https://dspace.library.colostate.edu

31. GIAKOUMIS, E., Renewable Energy, 50, 2013, p. 858.

32. BARABAS, I., TODORUT, I. A, www.intechopen.com

33. DIWAKAR ,B. T., DUTTA, P. K., LOKESH, B. R., NAID, K. A., J. Am. Oil. Chem. Soc., 87, 2010, p. 539.

Manuscript received: 27.10.2018 